\title{
DAMPAK MEA TERHADAP INVESTASI, EKSPOR-IMPOR DAN PENGGUNAAN TENAGA KERJA INDONESIA
}

\author{
Nur Khasanah, Prihartini Budi Astuti, Ika Neni Kristanti \\ e-mail:
}

\begin{abstract}
This research attempts to analyze the effects of the economic integration of the ASEAN Economic Community (AEC) which was implemented since 2015. The impact analyzed is focused on investments made in Indonesia, both investments made by foreign investors and domestic investors. Another thing that was also highlighted in this study was the flow of exports and imports. This was also investigated because one of the policies contained in the agreement of the ASEAN economic community was the elimination of international trade barriers. In addition to the two things above, researchers also analyzed the influence of the ASEAN economic community on the use of labor in Indonesia. The data analyzed in this study are secondary data obtained from the relevant agencies. The method used in this study is a different sample pair test. This method is used because the research conducted is comparing the conditions of investment, export-import and use of labor in Indonesia before and after the economic integration of the ASEAN Economic Community. At the end of this study, researchers will provide recommendations to the government regarding what should be done by the government to optimize investment activities, exports and use of local labor in Indonesia.
\end{abstract}

Keywords: ASEAN Economic Community, investment, import-export, use of labor

\subsection{Latar Belakang}

Negara-negara yang tergabung dalam integrasi ekonomi ASEAN telah menyepakati untuk diberlakukannya Masyarakat Ekonomi ASEAN atau MEA sejak akhir tahun 2015. Masyarakat Ekonomi ASEAN atau MEA memiliki dampak positif sekaligus negatif yang dirasakan oleh seluruh negara anggota MEA. Dampak positifnya adalah semakin lancarnya arus ekspor-impor barang dan jasa, investasi, tenaga kerja terampil, dan aliran modal karena hambatan-hambatan perdagangan internasional yang ada lebih diringankan bahkan dihilangkan. Kondisi tersebut merupakan suatu peluang dan juga sebagai ancaman. Peluang bagi negara-negara yang bisa bersaing dengan anggota negara MEA yang lain dari sisi sumber daya manusia, kualitas produk, dan lain sebagainya. Ancamannya adalah ketika negara MEA tidak mampu bersaing dengan negara anggota MEA yang lain.

Tidak berlakunya tarif ekspor impor untuk barang-barang tertentu seharusnya dimanfaatkan sebaik-baiknya oleh negara anggota MEA untuk bisa lebih banyak menjual produknya ke negara sesama anggota MEA. Setelah MEA berlaku, Indonesia berharap bisa meningkatkan ekspor yang dilakukan. Akan tetapi, saat ini yang terjadi adalah masyarakat Indonesia semakin gencar melakukan impor. Kondisi ini tentu berkebalikan dengan tujuan awal disepakatinya MEA oleh Indonesia. Bukti bahwa di Indonesia lebih banyak melakukan impor dari sebelum disepakatinya MEA adalah semakin banyaknya aktivitas perdagangan online yang dilakukan oleh masyarakat Indonesia baik yang berstatus mahasiswa maupun ibu rumah tangga dengan menjual barangbarang impor. 
Beberapa hal yang memicu makin maraknya perdagangan online yang menjual barang-barang impor oleh masyarakat Indonesia adalah lemahnya daya saing produk lokal. Secara umum, kualitas produk dalam negeri lebih rendah dari kualitas produk luar negeri. Hal ini yang menyebabkan masyarakat Indonesia semakin menyukai impor. Hal ini diperparah dengan harga jual produk impor yang murah. Harga yang semakin murah membuat masyarakat kalangan ekonomi menengah ke bawah mampu membeli barangbarang impor. Hal ini tentu semakin meningkatkan aktivitas impor yang dilakukan. Bagaimana tidak jika dengan harga yang hampir sama masyarakat bisa mendapatkan barang impor yang kualitasnya lebih baik dari barang lokal.

Mengingat dengan tumbuhnya investasi yang baik akan meningkatkan penyerapan tenaga kerja di Indonesia, berlakunya integrasi ekonomi MEA tidak hanya diharapkan menguntungkan di bidang ekspor dan impor saja, tapi di bidang investasi pun diharapkan akan menguntungkan negara Indonesia. Hal ini terjadi karena salah satu kesepakatan yang tertuang dalam integrasi ekonomi MEA pun membahas mengenai kemudahan arus investasi yang akan dijalankan di negara-negara anggota MEA. Peluang sekaligus ancaman pun dihadapi oleh Indonesia pada saat ini. Peluangnya adalah ketika Indonesia berhasil mengundang investor asing lebih banyak ke Indonesia, maka jumlah investasi yang ada di Indonesia pun akan meningkat tajam. Akan tetapi sebaliknya, jika negara anggota MEA lain jauh lebih menarik dalam menawarkan negaranya untuk berinvestasi maka investor dari dalam negeri pun bisa saja akan memilih untuk berinvestasi di luar negeri. Apabila jumlah investasi turun, ini berdampak pada meningkatnya pengangguran di Indonesia.

Selain dua hal tersebut, dalam kesepakatan MEA pun tertuang mengenai kesepakatan kemu- dahan arus tenaga kerja antara anggota negara MEA. Artinya, jika warga negara Indonesia bisa memanfaatkan kesempatan yang ada, mereka bisa bekerja di negara-negara anggota MEA manapun dengan lebih mudah. Akan tetapi, jika masyarakat tidak bisa memanfaatkan peluang yang ada maka MEA merupakan sebuah ancaman untuk Indonesia karena Indonesia akan diserbu oleh tenaga kerja asing jauh lebih banyak dari sebelumnya.

Berdasarkan pada kondisi tersebut peneliti tertarik untuk melakukan penelitian yang berfokus pada dampak integrasi ekonomi Masyarakat Ekonomi ASEAN terhadap investasi, eksporimpor dan penggunaan tenaga kerja di Indonesia.

\subsection{Perumusan Masalah}

Perumusan masalah dalam penelitian ini adalah sebagai berikut.

1. Integrasi ekonomi MEA beserta pengaruhnya terhadap investasi di Indonesia.

2. Integrasi ekonomi MEA beserta pengaruhnya terhadap penggunaan tenaga kerja di Indonesia.

3. Integrasi ekonomi MEA beserta pengaruhnya terhadap ekspor-impor di Indonesia.

\subsection{Batasan Masalah}

Pembatasan permasalahan perlu dilakukan agar penelitian fokus dan terarah. Penelitian ini dibatasi pada beberapa hal berikut.

1. Investasi yang akan dibahas dalam penelitian ini adalah investasi asing yang masuk ke Indonesia maupun investasi dalam negeri yang dilakukan di Indonesia sebelum dan sesudah diberlakukan MEA.

2. Ekspor-impor yang akan dibahas dalam penelitian ini adalah ekspor-impor yang dilakukan 
oleh Indonesia sebelum dan sesudah diberlakukan MEA.

3. Penggunaan tenaga kerja yang akan dibahas dalam penelitian ini adalah penggunaan tenaga kerja lokal sebelum dan sesudah diberlakukan MEA.

\subsection{Landasan Teori}

\subsubsection{Teori Klasik tentang Perdagangan Interna- sional}

\section{Pandangan Merkantilis mengenai perda- gangan}

Salvator (1997) mengatakan bahwa satusatunya cara bagi sebuah negara untuk menjadi kaya dan kuat adalah dengan melakukan sebanyak mungkin ekspor dan sesedikit mungkin impor. Surplus ekspor selanjutnya akan dibentuk dalam aliran emas lantakan atau logam mulia khususnya emas dan perak. Semakin banyak emas dan perak yang dimiliki oleh suatu negara, maka semakin kaya dan kuat negara tersebut. Hal tersebut membuat pemerintah mendorong untuk menggunakan seluruh kekuatannya untuk meningkatkan ekspor dan mengurangi impor, khususnya impor barang mewah. Akan tetapi, karena setiap negara tidak secara simultan dapat menghasilkan surplus ekspor dan karena jumlah emas dan perak tetap pada suatu saat tertentu, maka suatu negara hanya dapat memperoleh keuntungan dengan mengorbankan negara lain. Oleh karena itu, merkantilis menyebarluaskan nasionalisme ekonomi dan percaya bahwa di sini akan timbul konflik kepentingan nasional.

Salvator (1997) mengutip pernyataan Smith mengenai perdagangan internasional yang dilakukan secara suka rela. Dua negara akan melakukan perdagangan suka rela jika kedua negara tersebut memperoleh keuntungan. Jika salah satu negara memperoleh keuntungan dari perda- gangan internasional sedangkan satu negara mengalami kerugian, maka hal ini akan mendorong penolakan terhadap perdagangan.

\section{Keunggulan Absolut}

Salvator (1997) mengatakan bahwa jika sebuah negara lebih efisien dari pada negara lain atau memiliki keunggulan absolut dalam memproduksi sebuah komoditi, namun kurang efisien atau memiliki kerugian absolut dibanding negara lain dalam memproduksi komoditi lainnya, kedua negara tersebut dapat memperoleh keuntungan dalam perdagangan internasional dengan cara masing-masing melakukan spesialisasi dalam memproduksi komoditi yang memiliki keunggulan absolut dan menukarkannya dengan barang yang memiliki kerugian absolut. Melalui cara ini sumber daya yang ada di kedua negara tersebut dapat digunakan dalam cara yang paling efisien. Output yang diproduksi pun akan meningkat. Peningkatan dalam output ini akan mengukur keuntungan dari spesialisasi produksi untuk kedua negara yang melakukan perdagangan.

\section{Keunggulan Komparatif}

Meskipun sebuah negara kurang efisien dibanding negara lain dalam memproduksi kedua komoditi atau memiliki kerugian absolut, namun masih bisa melaksanakan perdagangan yang menguntungkan kedua belah pihak. Negara pertama harus melakukan spesialisasi dalam memproduksi dan mengekspor komoditi yang memiliki kerugian absolut lebih besar (komoditi ini memiliki kerugian komparatif).

\section{Biaya Relatif}

Menurut David Ricardo dalam Nopirin, (2010), titik pangkal teori perdagangan interna- 
sional adalah teorinya tentang nilai atau value. Menurut Ricardo nilai atau value suatu barang tergantung dari banyaknya tenaga kerja yang dicurahkan untuk memproduksi barang tersebut (labor cost value theory). Perdagangan antarnegara akan timbul jika masing-masing negara memiliki comparative cost yang kecil.

\subsubsection{Teori Modern tentang Perdagangan Inter- nasional}

\section{Faktor Proporsi (Hecksher \& Ohlin)}

Hecksher \& Ohlin dalam Nopirin (2010) menyatakan bahwa perbedaan dalam opportunity cost suatu negara dengan negara lain karena adanya perbedaan dalam jumlah faktor produksi yang dimilikinya. Suatu negara memiliki lebih banyak tenaga kerja daripada negara lain, sedangkan negara lain memiliki modal lebih banyak dari pada negara tersebut sehingga dapat menyebabkan terjadinya pertukaran.

\section{Kesamaan Harga Faktor Produksi}

Inti dari teori ini adalah bahwa perdagangan bebas cenderung mengakibatkan harga faktor produksi sama di beberapa negara. Mengacu pada teori faktor proportions Hecksher Ohlin, selama negara A memperbanyak produksi barang $\mathrm{X}$ akan mengakibatkan bertambahnya permintaan tenaga kerja, sebaliknya makin berkurang produksi barang Y berarti makin sedikitnya permintaan akan kapital. Hal ini akan cenderung menurunkan upah (harga dari pada tenaga kerja) dan menaikkan harga dari pada kapital (rate of return).

\section{Teori Permintaan dan Penawaran}

Pada prinsipnya, perdagangan antar-dua negara timbul karena adanya perbedaan dalam per- mintaan maupun penawaran. Perbedaan permintaan ini bisa disebabkan oleh pendapatan dan selera misalnya, sedangkan perbedaan penawaran dikarenakan misalnya karena perbedaan di dalam jumlah dan kualitas faktor-faktor produksi, tingkat teknologi, dan eksternalitas.

\subsubsection{Investasi}

Investasi adalah penanaman modal untuk satu atau lebih aktiva yang dimiliki dan biasanya berjangka waktu lama dengan harapan mendapatkan keuntungan di masa-masa yang akan datang. Investasi dalam arti luas terdiri dari dua bagian utama berikut (Sunariyah, 2011: 4).

1. Investasi dalam bentuk aktiva riil (real assets) adalah aktiva berwujud seperti emas, perak, intan, barang-barang seni, dan real estate.

2. Investasi dalam bentuk surat-surat berharga atau sekuritas (marketable securities atau $f i$ nancial assets) adalah aktiva finansial yang berwujud surat-surat berharga yang pada dasarnya merupakan klaim atas aktiva riil yang dikuasai oleh suatu entitas.

Ada beberapa alasan orang berinvestasi (Zvi Bodied and Alex Kane, 2006 dalam Andrianik, 2012:20).

a. Untuk mendapatkan kehidupan yang lebih layak di masa yang akan datang.

b. Mengurangi tekanan inflasi. Dengan melakukan investasi dalam kepemilikan perusahaan atau objek lain, seseorang dapat menghindari diri dari risiko penurunan nilai kekayaan atau hak milik akibat adanya inflasi.

c. Dorongan untuk menghemat pajak. Di beberapa negara di dunia banyak melakukan kebijakan yang bersifat mendorong tumbuhnya investasi di masyarakat melalui pemberitahuan fasilitas perpajakan kepada masyarakat yang melakukan investasi pada usaha tertentu. 


\subsubsection{Tenaga kerja}

Menurut UU Ketenagakerjaan No. 13 Tahun 2003 Bab 1 Pasal 1 Ayat 2. Tenaga kerja adalah setiap orang yang mampu melakukan pekerjaan guna menghasilkan barang dan atau jasa baik untuk memenuhi kebutuhan sendiri maupun untuk masyarakat. Penduduk yang memasuki usia kerja adalah mereka yang berusia antara 15-64 tahun.

Menurut simanjuntak (2005), tenaga kerja mencakup penduduk yang sudah dan sedang bekerja, sedang mencari pekerjaan dan yang melakukan kegiatan lain seperti bersekolah dan mengurus rumah tangga. Pencari kerja, bersekolah, dan mengurus rumah tangga, walaupun tidak bekerja, mereka dianggap secara fisik mampu dan sewaktu-waktu dapat ikut bekerja.

Menurut Sumarsono (2003:6) tenaga kerja adalah semua orang yang bersedia sanggup bekerja, di mana tenaga kerja ini meliputi semua orang yang bekerja baik untuk diri sendiri ataupun untuk anggota keluarganya yang tidak menerima imbalan dalam bentuk upah atau semua orang yang sesungguhnya bersedia dan mampu untuk bekerja, dalam arti mereka yang sesungguhnya bersedia dan mampu untuk bekerja, dalam arti mereka menganggur dengan terpaksa karena tidak adanya kesempatan kerja.

\subsubsection{Masyarakat Ekonomi ASEAN (MEA)}

\section{Definisi Masyarakat Ekonomi ASEAN (MEA)}

Masyarakat Ekonomi ASEAN (MEA) adalah suatu integrasi ekonomi yang bertujuan untuk meningkatkan daya saing ASEAN serta bisa menyaingi Cina dan India untuk menarik investasi asing. Penanaman modal asing di wilayah ini sangat dibutuhkan untuk meningkatkan lapangan pekerjaan dan meningkatkan kesejah- teraan. Masyarakat Ekonomi ASEAN (MEA) memungkinkan satu negara menjual barang dan jasa dengan mudah ke negara-negara lain di seluruh Asia Tenggara sehingga kompetisi akan semakin ketat. Masyarakat Ekonomi ASEAN tidak hanya membuka arus perdagangan barang atau jasa, tetapi juga pasar tenaga kerja profesional, seperti dokter, pengacara, akuntan, dan lainnya. MEA mensyaratkan adanya penghapusan aturan-aturan yang sebelumnya menghalangi perekrutan tenaga kerja asing. MEA akan lebih membuka peluang tenaga kerja asing untuk mengisi berbagai jabatan serta profesi di Indonesia yang tertutup atau minim tenaga asingnya. Akan tetapi pemerintahan Indonesia tetap masih melindungi tenaga kerja Indonesia dengan membuat syarat-syarat yang lebih ketat bagi warga negara asing yang akan bekerja di Indonesia. Contohnya adalah calon tenaga kerja yang berasal dari luar negeri harus mampu berbahasa asing dan harus memiliki sertifikasi lembaga profesi terkait di dalam negeri, (bbc.com).

\section{Keuntungan MEA bagi Negara-Negara Asia Tenggara}

Masyarakat Ekonomi ASEAN memiliki manfaat yang besar. Selain dapat menciptakan jutaan lapangan kerja baru, integrasi ekonomi ini juga dapat meningkatkan kesejahteraan 600 juta orang yang hidup di Asia Tenggara. International Labour Organization (ILO) merinci bahwa permintaan tenaga kerja profesional akan naik $41 \%$ atau sekitar 14 juta. Sementara permintaan akan tenaga kerja kelas menengah akan naik $22 \%$ atau 38 juta, sementara tenaga kerja level rendah meningkat 24\% atau 12 juta, (bbc.com). Artinya, dengan adanya MEA ini Indonesia memiliki kesempatan untuk dapat mengurangi pengangguran. 


\subsection{Penelitian Terdahulu}

Nur Khasanah, dan Prihartini Budi Astuti (2016) melakukan penelitian dengan judul Analisis Dampak Mea Terhadap Ekspor Impor Indonesia. Dalam penelitian tersebut diperoleh kesimpulan sebagai berikut: Nilai ekspor Indonesia setelah diberlakukannya MEA mencapai US $\$ 12,63$ miliar menurun 0,74 persen. Ekspor nonmigas Agustus 2016 mencapai US\$11,50 miliar, dibanding ekspor Agustus 2015 naik 2,76 persen. Sedangkan Nilai impor Indonesia Agustus 2016 mencapai US $\$ 12,34$ miliar turun 0,49 persen jika dibandingkan Agustus 2015. Impor nonmigas Agustus 2016 mencapai US\$10,58 miliar apabila dibandingkan Agustus 2015 naik 2,84 persen. Impor migas Agustus 2016 mencapai US $\$ 1,76$ miliar atau turun 16,71 persen jika dibandingkan Agustus 2015.

Secara umum penurunan nilai ekspor dan impor Indonesia yang terjadi disebabkan karena terjadi pelemahan kegiatan ekonomi global, permintaan maupun penawaran barang menurun, daya beli masyarakat menurun, investasi dalam negeri menurun, pembelanjaan pemerintah (government spending) menurun karena realisasi APBN saat ini tidak optimal.

\subsection{Kerangka Penelitian}

Kerangka penelitian dibuat untuk memberikan gambaran arah penelitian yang akan dilakukan.

\subsection{Hipotesis Penelitian}

Hipotesis merupakan dugaan awal penelitian. Dalam penelitian ini, peneliti mengajukan hipotesis sebagai berikut.

1. $\mathrm{H}_{1}$ : terdapat perbedaan kondisi ekspor yang ada di Indonesia sebelum dan sesudah diberlakukannya MEA.
2. $\mathrm{H}_{2}$ : terdapat perbedaan kondisi impor yang ada di Indonesia sebelum dan sesudah diberlakukannya MEA.

3. $\mathrm{H}_{3}$ : terdapat perbedaan kondisi penggunaan tenaga kerja yang ada di Indonesia sebelum dan sesudah diberlakukannya MEA.

4. $\mathrm{H}_{4}$ : terdapat perbedaan kondisi investasi yang ada di Indonesia sebelum dan sesudah diberlakukannya MEA.

\section{TUJUAN DAN MANFAAT}

\subsection{Tujuan Penelitian}

Penelitian ini bertujuan untuk beberapa hal sebagai berikut.

1. Menganalisis dampak diberlakukannya integrasi ekonomi MEA terhadap kondisi investasi di Indonesia.

2. Menganalisis dampak diberlakukannya integrasi ekonomi MEA terhadap kondisi penggunaan tenaga kerja di Indonesia.

3. Menganalisis dampak diberlakukannya integrasi ekonomi MEA terhadap kondisi eksporimpor di Indonesia.

\subsection{Manfaat Penelitian}

Penelitian ini diharapkan bermanfaat, baik secara praktis maupun teoretis.

\section{Manfaat praktis}

Penelitian ini diharapkan mampu memberikan masukan kepada pemerintah dalam pengambilan keputusan yang berkaitan dengan pemberlakuan integrasi ekonomi, kebijakan yang berkaitan dengan ketenagakerjaan, perdagangan internasional dan kebijakan investasi. 


\section{Manfaat teoretis}

Secara teoretis, penelitian ini diharapkan dapat menambah referensi mengenai integrasi ekonomi khususnya Masyarakat Ekonomi ASEAN, penggunaan tenaga kerja, ekspor dan impor serta investasi.

\section{METODE PENELITIAN}

\subsection{Jenis Penelitian}

Penelitian ini menggunakan metode penelitian kuantitatif. Metode kuantitatif digunakan untuk menganalisis perbandingan tingkat investasi sebelum dan sesudah berlakunya integrasi ekonomi Masyarakat Ekonomi ASEAN (MEA), tingkat ekspor-impor yang dilakukan oleh Indonesia sebelum dan sesudah berlakunya integrasi ekonomi Masyarakat Ekonomi ASEAN (MEA), tingkat penggunaan tenaga kerja Indonesia sebelum dan sesudah berlakunya integrasi ekonomi Masyarakat Ekonomi ASEAN (MEA).

\subsection{Sumber Data}

Data yang digunakan dalam penelitian ini adalah data sekunder. Data sekunder merupakan data primer yang diperoleh oleh pihak lain atau data primer yang telah diolah lebih lanjut dan disajikan oleh pengumpulan data primer atau pihak lain. Data sekunder pada umumnya digunakan oleh peneliti untuk memberikan gambaran tambahan, gambaran pelengkap, ataupun untuk diproses lebih lanjut (Siagian dan Sugiarto, 2006:17). Data sekunder dalam penelitian ini adalah data atau catatan yang diperoleh dari Kementerian Tenaga Kerja, Kementerian Perindustrian Republik Indonesia dan Badan Koordinasi dan Penanaman Modal Indonesia.

\subsection{Variabel Penelitian dan Definisi Operasional Variabel}

\section{Variabel Penelitian}

Variabel penelitian merupakan gejala yang menjadi fokus untuk diamati oleh peneliti, sebagai atribut dari kelompok orang atau objek yang mempunyai variasi antara satu dengan lainnya dalam kelompok tersebut. Variabel dalam penelitian ini adalah investasi, ekspor-impor dan penggunaan tenaga kerja.

\section{Definisi operasional variabel}

a. Investasi

Investasi adalah penanaman modal untuk satu atau lebih aktiva yang dimiliki dan biasanya berjangka waktu lama dengan harapan mendapatkan keuntungan di masa-masa yang akan datang (Sunariyah, 2011: 4).

b. Ekspor-impor

Ekspor adalah aktivitas penjualan suatu produk ke luar negeri. Impor adalah aktivitas pembelian produk dari luar negeri.

c. Penggunaan tenaga kerja

Menurut UU Ketenagakerjaan No.13 tahun 2003 Bab 1 pasal 1 ayat 2. Tenaga kerja adalah setiap orang yang mampu melakukan pekerjaan guna menghasilkan barang dan atau jasa baik untuk memenuhi kebutuhan sendiri maupun untuk masyarakat.

\subsection{Populasi dan Sampel}

\section{Populasi Penelitian}

Populasi adalah wilayah generalisasi yang mempunyai kualitas dan karakteristik tertentu yang ditetapkan oleh peneliti untuk dipelajari dan kemudian ditarik kesimpulannya (Sugiyono, 2005:41). Populasi dalam penelitian ini adalah 
data investasi, data ekspor-impor, dan data penggunaan tenaga kerja di Indonesia.

\section{Sampel Penelitian}

Sampel adalah sebagian dari jumlah dan karakteristik yang dimiliki oleh populasi tersebut (Sugiyono, 2006:73). Semakin banyak sampel, semakin representatif datanya, namun perlu diperhatikan juga masalah tenaga, dana, dan waktu. Menurut Arikunto (2002:112) untuk sampel apabila subjeknya kurang dari 100, lebih baik diambil semua sehingga penelitiannya merupakan penelitian populasi, dan jika jumlah subjeknya besar dapat diambil antara $10-15 \%$, atau 20$25 \%$, atau lebih.

\subsection{Metode Pengambilan Sampel}

Metode pengambilan sampel adalah suatu teknik dalam penarikan atau pengambilan sampel penelitian. Metode pengambilan sampel dalam penelitian ini adalah metode times series design, yaitu desain penelitian yang bermaksud untuk mengetahui kestabilan dan kejelasan suatu keadaan yang tidak menentu dan tidak konsisten.

\subsection{Metode Pengumpulan Data}

Metode pengumpulan data yang dilakukan dalam penelitian ini adalah dengan menggunakan metode Dokumentasi. Menurut Sukardi (2003), metode dokumentasi dalam penelitian ini dimaksudkan untuk memperoleh data dengan cara dokumentasi, yaitu mempelajari dokumen yang berkaitan dengan seluruh data yang diperlukan dalam penelitian. Dokumentasi dari asal kata dokumen yang artinya barang-barang tertulis. Di dalam melaksanakan metode dokumentasi, peneliti menyelidiki benda-benda tertulis seperti data investasi, data ekspor-impor dan data penggunaan tenaga kerja.

\subsection{Rancangan Alat Analisis Data}

Penelitian ini bertujuan untuk mengetahui apakah ada perbedaan tingkat investasi, tingkat ekspor-impor dan tingkat penggunaan tenaga kerja sebelum dan sesudah diberlakukannya integrasi ekonomi masyarakat ekonomi ASEAN. Oleh karena itu penelitian ini menggunakan uji beda t-test dengan sampel berhubungan (related samples). Uji beda dengan sampel berhubungan dilakukan dengan menggunakan uji statistik Wilcoxon match pair test yang dilakukan menggunakan bantuan program SPSS 22. Menurut Sugiyono (2010), Wilcoxon match pair test digunakan untuk menguji hipotesis komparatif dua sampel yang berhubungan bila datanya berbentuk ordinal. Rancangan penelitian berbentuk before after. Jadi hipotesis penelitian merupakan perbandingan nilai sebelum dan sesudah ada perlakuan/treatment, untuk membuktikan ada tidaknya perubahan.

\section{HASIL DAN LUARAN YANG DICAPAI}

\subsection{Gambaran Umum tentang Indonesia}

Indonesia merupakan sebuah negara yang memiliki penduduk yang banyak. Penduduk yang padat merupakan sebuah peluang sekaligus ancaman bagi Indonesia. Penduduk menjadi peluang karena penduduk memiliki posisi ganda, yaitu sebagai tenaga kerja sekaligus konsumen. Jika sebuah negara memiliki tenaga kerja yang banyak, artinya negara tersebut memiliki potensi untuk memperoleh tenaga kerja yang harganya murah, karena semua tenaga kerja menginginkan untuk memperoleh pekerjaan agar bisa bertahan hidup. Akan tetapi jika melimpahnya tenaga kerja tidak diimbangi dengan ketersediaan lapangan pekerjaan yang cukup, maka hadirnya tenaga kerja yang melimpah tersebut justru menjadi ancaman bagi negara. Hal ini terjadi karena 
tenaga kerja yang tidak memperoleh pekerjaan akan menganggur sehingga dia tidak memperoleh pendapatan untuk melakukan memenuhi kebutuhan hidupnya. Pada akhirnya permasalahan tentang pengangguran ini bukan hanya menjadi permasalahan pribadi dan keluarga saja, tetapi juga menjadi permasalahan lingkungan dan juga negara. Menjadi permasalahan lingkungan karena menimbulkan biaya sosial bagi lingkungan sekitar. Hal ini menjadi permasalahan negara karena salah satu dampak pengangguran adalah meningkatnya angka kriminalitas yang bisa dilakukan oleh para penganggur.

Posisi penduduk sebagai konsumen membuat peluang bisnis di Indonesia semakin bagus, karena dengan penduduk yang banyak maka potensi penjualan produk pun akan meningkat. Hal ini didukung pula dengan disepakatinya integrasi ekonomi Masyarakat Ekonomi ASEAN (MEA) oleh negara Indonesia dan negara-negara anggota ASEAN.

Selain permasalahan pengangguran yang diharapkan bisa segera teratasi setelah diberlakukannya MEA, masalah lain yang diharapkan bisa terselesaikan adalah masalah ekspor dan impor serta investasi.

\subsection{Kondisi Ekspor dan Impor Indonesia Sebelum dan Sesudah Berlakunya MEA}

Perdagangan bebas yang disepakati oleh negara-negara ASEAN mulai diberlakukan pada akhir 2015. Setelah diberlakukannya MEA, tingkat ekspor yang dilakukan oleh Indonesia masih mengalami fluktuasi, baik itu naik ataupun turun.

\section{Ekspor}

Fluktuasi ekspor yang dilakukan bisa dilihat dari data ekspor yang dirilis oleh berbagai media.
Sebelum MEA diberlakukan pada tahun 2013 sampai MEA telah diberlakukan tingkat ekspor yang dilakukan oleh Indonesia untuk produk primer selalu mengalami penurunan. Akan tetapi, tingkat ekspor pada produk manufaktur mengalami peningkatan dari waktu ke waktu.

Tingkat ekspor yang dilakukan oleh Indonesia mengalami fluktuasi dari waktu ke waktu. Sebelum MEA ekspor Indonesia ke Singapura stagnan tetapi di tahun pertama diberlakukannya MEA tingkat ekspor Indonesia mengalami kenaikan. Namun sayangnya kemudian mengalami penurunan kembali di tahun 2017. Ekspor ke Malaysia dan Thailand pun mengalami fluktuasi dari waktu ke waktu. Ekspor yang mengalami peningkatan adalah ekspor ke Filipina. Secara umum kondisi ini terjadi karena pergeseran selera konsumen.

Sebagian besar ekspor Indonesia mengalami fluktuasi. Kondisi tersebut disebabkan karena berubah-ubahnya selera konsumen, ketidakpastian tingkat kebutuhan konsumen, serta persaingan dengan negara-negara yang menghasilkan produk sejenis.

Perolehan hasil pengolahan data ekspor barang berdasarkan kelompok barang menunjukkan angka signifikansi sebesar 0,249. Angka ini lebih besar dari 0,05. Oleh karena itu hipotesis dalam penelitian ini ditolak. Hasil perolehan uji statistik ekspor berdasarkan komoditi sebelum dan sesudah MEA menunjukkan angka signifikansi sebesar 0,906 >0,05. Selain itu pengujian terhadap data ekspor berdasarkan negara tujuan sebelum dan sesudah MEA menunjukkan angka signifikansi sebesar 0,854 atau lebih besar dari 0,05 sehingga bisa disimpulkan bahwa hipotesis 1 tidak dapat diterima. Hasil analisis menunjukkan bahwa tidak terdapat perbedaan yang signifikan antara kondisi ekspor sebelum dan sesudah diberlakukannya MEA. 


\section{Impor}

Tingkat impor yang dilakukan oleh Indonesia sebelum dan sesudah MEA pun mengalami fluktuasi.

Impor barang konsumsi yang dilakukan oleh Indonesia selalu mengalami peningkatan dari waktu ke waktu. Hal ini menandakan bahwa kemampuan berkonsumsi yang dilakukan oleh masyarakat Indonesia mengalami peningkatan, dan kemampuan berkonsumsinya dilakukan untuk membeli produk dari luar negeri. Kondisi ini tidak boleh dibiarkan berlarut-larut karena bisa membahayakan kondisi perekonomian dalam negeri, produk yang diciptakan oleh pengusaha lokal tidak begitu laku di pasaran. Harus dilakukan berbagai upaya untuk mengatasinya, mulai dari peningkatan daya saing produk sampai efisiensi proses produksi agar harga produk lebih kompetitif di pasar domestik.

Impor terhadap barang bahan baku yang dilakukan oleh Indonesia pun mengalami peningkatan dari waktu ke waktu. Hal ini menggambarkan bahwa industri domestik Indonesia cukup tergantung dengan bahan-bahan impor. Sedangkan belanja barang modal yang dilakukan oleh Indonesia lebih fluktuatif dibandingkan dengan yang lain.

Impor pada barang konsumsi yang dilakukan oleh Indonesia secara umum mengalami penurunan sebelum MEA tetapi mengalami kenaikan kembali di tahun kedua setelah diberlakukannya MEA. Kondisi yang relatif sama juga terjadi pada impor bahan baku atau penolong. Akan tetapi, pada barang modal kecenderungan impor yang dilakukan mengalami penurunan.

Impor yang dilakukan oleh Indonesia dari negara Singapura sebelum MEA cenderung mengalami peningkatan dari waktu ke waktu tetapi mengalami penurunan di tahun pertama diberlakukannya MEA dan meningkat lagi di tahun 2017. Impor Indonesia dari Thailand menurun sebelum MEA, naik lagi pada tahun pertama setelah diberlakukannya MEA dan kembali menurun pada tahun 2017. Sedangkan aktivitas impor yang dilakukan oleh Indonesia dari Malaysia lebih fluktuatif dari waktu ke waktu.

Impor berdasarkan jenis barang sebelum dan sesudah MEA memperoleh angka signifikansi sebesar 0,842>0,05. Impor berdasarkan kelompok barang sebelum dan sesudah MEA memperoleh angka signifikansi sebesar 0,249 > 0,05 dan impor berdasarkan negara asal barang memperoleh nilai signifikansi sebesar 0,593 > 0,05 . Perolehan angka signifikansi yang lebih besar dari 0,05 membuktikan bahwa hipotesis ditolak. Artinya, tidak ada perbedaan antara kondisi impor sebelum dan sesudah diterapkannya integrasi ekonomi MEA.

\subsection{Kondisi Tenaga Kerja di Indonesia}

Selain kondisi ekspor dan impor, penelitian ini pun fokus membahas tentang kondisi tenaga kerja Indonesia.

Terdapat peningkatan penyerapan tenaga kerja pada saat MEA telah diterapkan. Kondisi ini merupakan sebuah keuntungan yang dialami oleh Indonesia karena penerapan MEA.

Jumlah penduduk usia kerja mengalami peningkatan sebelum dan sesudah MEA. Penduduk yang memiliki pekerjaan pun mengalami peningkatan, sedangkan pengangguran yang ada di Indonesia mengalami penurunan.

Angka signifikansi penyerapan tenaga kerja sebelum dan sesudah MEA sebesar 0,889 > 0,05 dan bidang kerja sebelum dan sesudah MEA sebesar 0,68 >0,05. Analisis tersebut membuktikan bahwa hipotesis yang menyatakan bahwa terdapat perbedaan kondisi tenaga kerja 
sebelum dan sesudah MEA ditolak. Dengan kata lain, tidak ada perbedaan kondisi tenaga kerja antara sebelum dan sesudah diberlakukannya MEA.

\subsection{Kondisi Investasi di Indonesia}

Selain masalah ekspor dan impor serta tenaga kerja, salah satu kesepakatan MEA adalah mengenai kemudahan arus investasi yang dilakukan di negara-negara anggota MEA. Oleh karena itulah peneliti pun tertarik untuk menganalisis perbedaan kondisi investasi sebelum dan sesudah MEA.

Secara umum investasi yang dilakukan oleh investor dalam negeri di dalam negeri mengalami peningkatan setelah diterapkannya MEA. Hal ini berarti Indonesia memperoleh manfaat dari diberlakukannya MEA.

Kenaikan investasi yang terjadi disebabkan oleh kebijakan baru yang diterapkan oleh Indonesia untuk memudahkan proses pengurusan investasi. Tujuan dari kebijakan ini untuk meningkatkan penggunaan tenaga kerja di Indonesia.

Negara dengan investasi terbanyak adalah Singapura dengan nilai 1281,1 pada sebelum MEA dan 2053,6 sesudah MEA. Investor dari MEA yang menempati peringkat kedua adalah Malaysia yaitu 100,7 pada sebelum MEA dan 271,9 setelah MEA.

Di beberapa daerah ada yang mengalami peningkatan investasi setelah diberlakukannya MEA, tetapi di daerah lain ada yang mengalami penurunan. Kenaikan maupun penurunan investasi yang terjadi lebih disebabkan oleh kondisi geografis wilayah, daya beli konsumen maupun tingkat inflasi yang terjadi.

Investasi asing terbesar terletak di Jawa Barat dengan jumlah1767,4 sebelum MEA dan
1085,7 setelah MEA. Investasi yang terbesar kedua adalah kalimantan timur yaitu sebesar 798,6 sebelum MEA dan 242,4 sesudah MEA. Hampir di semua wilayah di Indonesia mengalami penurunan jumlah investasi setelah MEA.

Jenis investasi dalam negeri sebelum dan sesudah MEA memperoleh nilai signifikansi sebesar $0,010<0,05$, artinya hipotesis yang menyatakan bahwa terdapat perbedaan yang signifikan pada jenis investasi sebelum dan sesudah MEA diterima. Analisis yang telah dilakukan menghasilkan bahwa jenis investasi asing sebelum dan sesudah MEA sebesar 0,903 > 0,05, artinya tidak terdapat perbedaan kondisi jenis investasi asing sebelum dan sesudah MEA. Sedangkan data mengenai investasi menurut negara asal sebelum dan sesudah MEA sebesar 0,225 > 0,05 , artinya hipotesis ditolak. Dengan kata lain tidak terdapat perbedaan kondisi investasi menurut negara asal. Analisis data mengenai investasi menurut wilayah sebelum dan sesudah MEA menghasilkan angka signifikansi sebesar 0,02< 0,05 , artinya terdapat perbedaan yang signifikan pada investasi menurut wilayah. Hasil olah data mengenai investasi asing menurut wilayah setelah MEA dan sebelum MEA menunjukkan angka signifikansi sebesar 0,174 >0,05 artinya tidak terdapat perbedaan kondisi investasi asing menurut wilayah.

\section{DAFTAR RUJUKAN}

Andrianik. 2012. Analisis Faktor-Faktor yang Memengarubi Risiko Investasi Saham pada Perusahaan Farmasi yang Go Public di Bursa Efek Indonesia. Denpasar: Fakultas Ekonomi Universitas Warmadewa.

Nopirin. 2010. Ekonomi Moneter, Buku I, Edisi ke-4, Cetakan Kesepuluh. Yogyakarta: BPFE. 
Salvatore, Dominic. 1997. Ekonomi Internasional. Jakarta: Erlangga.

Sugiyono. 2009. Metode Penelitian Kuantitatif Kualitatif dan R\&D, Cet. ke-8, h. 137. Bandung: Alfabeta.

Sukardi. 2003. Metodologi Penelitian Pendidikan. Yogyakarta: Bumi Aksara.

Sunariyah. 2011. Pengantar Pengetahuan Pasar Modal, Edisi Keenam. Yogyakarta: Penerbit Sekolah Tinggi Ilmu Manajemen YKPN.
Sony Sumarsono. 2003. Manajemen Koperasi: Teori dan Praktik. Yogyakarta: Penerbit Graha Ilmu.

Simanjuntak, Payaman J. 2005. Manajemen dan Evaluasi Kerja. Lembaga. Jakarta: Penerbit FEUI.

Undang-Undang Republik Indonesia Nomor 13 Tahun 2003 tentang Tenaga Kerja. Bogor: Diperbanyak oleh Ghalia Indonesia. 